\title{
HUBUNGAN KONTEMPORER MALAYSIA - INDONESIA: TAHAP PENGETAHUAN DAN PEMAHAMAN GEN X DAN Y MALAYSIA
}

\author{
Rohani Hj. Ab Ghani ${ }^{1}$, Ahmad Shukri bin Abdul Hamid ${ }^{2}$, \\ Zulhilmi bin Paidi ${ }^{3}$, Mohan A/L Ratakrishnan ${ }^{4}$, \\ Rashidah binti Mamat ${ }^{5}$, Andi Tenri Yeyeng ${ }^{6}$ \\ Universiti Utara Malaysia $^{1-5}$, STKIP Pembangunan Indonesia Makassar ${ }^{6}$ \\ Email:rag1162@uum.edu.my1, shukri@uum.edu.my²,zul1085@uum.edu.my³, \\ mohan@uum.edu.my ${ }^{4}$, shidah@uum.edu.my ${ }^{5}$, yeyengtenri@yahoo.com ${ }^{6}$
}

\begin{abstract}
Abstrak
Hubungan Malaysia-Indonesia menunjukkan bahwa masyarakat turut dominan dalam mempengaruhi arah hubungan kedua negara. Dalam perbandingannya, masyarakat Indonesia lebih responsif dari pada masyarakat Malaysia terhadap isu-isu yang melibatkan hubungan kedua negara tersebut. Grup yang paling aktif adalah pada umumnya berasal dari generasi muda yang dikenal sebagai Generasi Y (Gen Y). Reaksi mereka jelas agak provokatif apabila muncul isu-isu yang berkaitan dengan Malaysia. Tujuan tulisan ini adalah untuk mendiskusikan pengetahuan dan persepsi Gen Y dan Gen X di Universiti Utara Malaysia (UUM) terhadap hubungan bilateral Malaysia-Indonesia dan faktor-faktor yang mempengaruhi pengetahuan dan persepsi mereka. Tulisan ini menggunakan metode kuantitatif dan kualitatif. Hasil penelitian menemukan bahwa responden menerima Indonesia sebagai negara tetangga yang diperlukan karena faktor kepentingan negara saat ini. Faktor hiburan seperti sinetron Indonesia dan lagu kontemporer memberikan pengaruh paling signifikan dalam mempengaruhi tingkat pengetahuan tentang negara Indonesia kepada responden. Selain itu, mereka juga mendapatkan banyak informasi tentang Indonesia melalui media elektronik. Temuan penting dari penelitian ini adalah semua responden mengakui bahwa Indonesia masih relevan sebagai tetangga terdekat Malaysia berdasarkan faktor kesamaan dan hubungan baik kedua negara perlu dipertahankan.
\end{abstract}

\section{Kata Kunci: \\ Hubungan Bilateral Malaysia-Indonesia, Provokatif, \\ Gen X, Gen Y, Sinetron Indonesia}

\begin{abstract}
Looking at the relations between Malaysia-Indonesia, it could be seen that society has the power to direct the bilateral relations between two countries. In comparison, Indonesian society is more responsive than Malaysian society in responding to particular issues related to both countries. The most active group is generally from the younger generation known as Generation $Y$ (Gen $Y)$ where their reactions tend to be provocative. The purpose of this paper is to discuss the knowledge and perceptions of Gen $Y$ and Gen X at Universiti Utara Malaysia (UUM) on the Malaysia-Indonesia bilateral relationship and the factors that influence their knowledge and perception. This paper uses quantitative and qualitative methods. The results of the study showed
\end{abstract}


that respondents accepted Indonesia as an important neighbor because of the current state's interests. The cultural and social aspects, particularly audio-visual products such as Indonesian soap operas and Indonesian pop songs have the most significant influence in influencing the respondents' level of knowledge about Indonesia. In addition, they also get a lot of information about Indonesia through electronic media. An important finding from this study is that all respondents acknowledge that Indonesia is still relevant as Malaysia's closest neighbor based on the similarity factor and those good relations between the two countries need to be maintained.

\section{Keywords: \\ Bilateral Relationship Indonesia-Malaysia, Provocative, Gen X, Gen Y, Indonesian Soap Opera}

\section{Pendahuluan}

Indonesia merupakan negara tetangga yang paling banyak memiliki kesamaan dengan Malaysia dibandingkan dengan daerah lain di kawasan Asia Tenggara. Kesamaan budaya, bahasa dan agama kedua negara dipengaruhi oleh sejarah lingkungan alam yang mendasari keberadaan peradaban Melayu di kedua negara tersebut. Beberapa kesamaan yang muncul tampaknya telah menciptakan nilai-nilai sentimental di kalangan masyarakat dan pemimpin di kedua negara di masa lalu. Nilai ini juga sebagai pengingat rasa persaudaraan di antara mereka di masa awal kemerdekaan Malaysia dan juga di antara Gen lama kedua negara. Namun, masalah ini tidak begitu signifikan untuk Gen muda pada khususnya. Di Indonesia, kaum muda menganggap Malaysia sebagai pesaing dalam segala aspek sedangkan kelompok yang sama di Malaysia menganggap Indonesia sebagai negara besar yang tidak menangani masalah ekonomi mereka dengan baik yang menyebabkan banyak dari mereka datang ke Malaysia untuk mencari nafkah.

Perkembangan ekonomi dan politik internasional dewasa ini semakin menunjukkan pentingnya kerjasama yang baik sehingga masyarakat di kedua negara harus memikirkan kembali pola hubungan yang akan dibangun meskipun pada saat yang sama, Malaysia-Indonesia tetap mempertahankan kepentingan nasionalnya. Sejalan dengan persoalan ini, pengetahuan masyarakat di kedua negara perlu ditelaah untuk mengetahui bagaimana pemahaman mereka terhadap negara tetangga yang selama ini digambarkan serumpun, sebangsa dan seagama namun masih terdapat ketegangan. Tulisan ini memberikan landasan untuk dua tujuan penelitian, yaitu untuk mengetahui faktor-faktor yang mempengaruhi tingkat pengetahuan dan pemahaman 
Gen $\mathrm{X}$ dan Y tentang hubungan bilateral Malaysia-Indonesia dan untuk menilai persepsi Gen X dan Y tentang hubungan bilateral Malaysia-Indonesia.

\section{Tinjauan Pustaka}

Septy Ruzui mengawali tulisannya dengan mengutip kata-kata dalam bahasa Indonesia, "tak kenal, maka tak sajang." Dalam bahasa Tagalog berbunyi "di-alam, dimahal" atau dalam bahasa Melayu adalah "tak kenal, maka tak cinta". Ruzui membahas mengenai hubungan tiga negara berasaskan kepada persamaan bahasa:

....Therefore, when tries to look at his neighbours as his friends, it is certain that he will contribute, no matter in how small a way, to a harmonious and close relationship between neighbouring countries and his. To understand your neighbours more is to get acquainted with their language, because language plays an important role in the life of people as a medium of communication. ${ }^{1}$

Dalam memahami hubungan Malaysia-Indonesia, persoalan bahasa bukan merupakan satu persoalan yang besar karena kedua negara bersandar kepada rumpun bahasa yang sama yaitu bahasa Melayu. ${ }^{2}$ Namun demikian, dalam sejarah hubungan Malaysia dengan negara-negara tetangga lainnya, Indonesia merupakan satu-satunya negara yang telah melancarkan konfrontasi bersenjata terhadap Malaysia pada tahun 1963-1966. Sebelum Malaysia mencapai kemerdekaan pada tahu 1957, Indonesia banyak berkontribusi terhadap pembangunan Malaysia khususnya dalam bidang pendidikan. Bantuan-bantuan tersebut bertujuan untuk membantu peningkatan pencapaian orang Melayu yang diidentikkan sebagai saudara. Kerjasama ini terhenti beberapa lama setelah tercetusnya konfrontasi, tetapi dilanjutkan kembali pada era 1970-an dan tahun-tahun setelah itu. ${ }^{3}$

Namun demikian, hubungan dengan tema keserumpunan telah beralih kepada kepentingan nasional. Isu pokok yang sering menimbulkan konflik di antara Malaysia dan Indonesia adalah persoalan perbatasan negara. Menurut Mak Joon Num, masalah

\footnotetext{
${ }^{1}$ Septy Ruzui, A Survey of Relations Between Indonesian, Malay and Some Philippine Languages (Kuala Lumpur: Dewan Bahasa dan Pustaka, 1986).

${ }^{2}$ Ahmad Nizar Yakub, Dances with Garuda: Malaysia-Indonesia Bilateral Relations (Samarahan: Universiti Malaysia Sarawak, 2013).

${ }^{3}$ Rohani Hj. Ab Ghani, “Dinamika Hubungan Malaysia-Indonesia: Satu Retro-Perspektif” dalam Seminar Internasional Malaysia-Indonesia, Fakultas Usuluddin dan Falsafat UIN Alauddin Makassar, 16-17 Oktober 2016.
} 
yang paling pokok adalah ketidakjelasan garis batas yang telah menjadi duri dalam daging terkait hubungan kedua negara tersebut. ${ }^{4}$ Selain itu, isu Tenaga Kerja Indonesia (TKI) di Malaysia juga menimbulkan masalah dalam hubungan kedua negara. Menjelang pertengahan tahun 1980-an, Malaysia menunjukkan peningkatan ekonomi yang jauh lebih tinggi dibanding Indonesia. Hal ini mendorong masuknya Warga Negara Indonesia (WNI) yang disebut sebagai Pendatang Asing Dengan Izin (PADI) bagi mereka yang mempunyai izin kerja dan Pendatang Asing Tanpa Izin (PATI) bagi mereka yang menyelinap masuk secara ilegal ke Malaysia. Berdasarkan arsip pemerintah Malaysia, saat ini terdapat lebih dari dua juta PATI di Malaysia dan sebagian besar dari mereka adalah WNI. Laporan dari Kementerian Dalam Negeri (KDN) menyatakan bahwa jumlah pekerja asing yang memegang Pas Lawatan Kerja Sementara (PLKS) sebanyak 1,781,598 orang dan dari jumlah ini, pekerja asing dari Indonesia tercatat jumlah tertinggi yaitu 728,870 orang diikuti Nepal $(405,898)$, Bangladesh (221,089), Myanmar (127, 705), India (114,455) dan Pakistan $(59,281){ }^{5}$

Menurut Azizah Kassim, peningkatan taraf hidup dan sistem pendidikan yang semakin baik telah mengubah persepsi masyarakat setempat terhadap jenis pekerjaan. Sehubungan dengan skenario ini, pekerjaan berupa tenaga kerja tidak terampil dan setengah terampil tidak lagi menjadi fokus sebagian penduduk asli Malaysia dan lowongan tersebut sebagian besar diisi oleh WNI. Sebagian besar mendominasi sektor pekerjaan yang bukan pilihan masyarakat sekitar, yaitu pekerjaan yang dikategorikan 4D, yaitu berbahaya (dangerous), susah (difficult), kotor (dirty) dan sampah (dust). ${ }^{6}$ Menurut Intan Suria Hamzah dan Sity Daud (2016), WNI sebenarnya menjadi stok untuk mengisi sektor-sektor ketenagakerjaan yang kritis di Malaysia. ${ }^{7}$

Dari segi pemahaman dan persepsi, penerimaan masyarakat Indonesia dan Malaysia terhadap isu-isu yang melibatkan keduanya cukup berbeda. Sebagai dasar perbandingan, masyarakat Indonesia lebih peka terhadap isu-isu yang berkaitan dengan

\footnotetext{
${ }^{4}$ Joon Num Mak, Domestic Politics and Conflict-Resolution in the South China Sea: China and the Spratly Disputes. Tidak Diterbitkan (2000).

${ }^{5}$ Bernama, "Lebih 1.7 Juta Pekerja Asing Pemegang Pas Lawatan Kerja Sementara" dalam http://www.astroawani.com/berita-malaysia/lebih-1-7-juta-pekerja-asing-pemegang-pas-lawatan-kerjasementara-150996 diakses 23 Oktober 2017.

"Azizah Kassim, "International Migration and its Impact on Malaysia" dalam Mohamed Jawhar Hassan (ed.), A Pacific Peace: Issues \& Responses (Kuala Lumpur: Institute Strategic and International Security, 1998).

${ }^{7}$ Intan Suria Hamzah \& Sity Daud, "Implikasi Kemasukan Pekerja Asing di Malaysia: Satu Tinjauan Awal” dalam Jurnal Sains Insani, Vol. 1, No. 1 (2016), h. 69-77.
} 
kepentingan negaranya dibandingkan dengan masyarakat negara lain. Dalam banyak situasi, masyarakat Indonesia tampaknya sangat responsif dan terkadang agresif terhadap Malaysia ketika masalah yang berkaitan dengan negara mereka muncul. Sikap ini agak berbeda jika ada masalah dengan negara selain Malaysia. Berkaitan dengan itu, para pakar hubungan Malaysia-Indonesia berpandangan bahwa masyarakat Indonesia sangat cepat bereaksi ketika muncul persoalan terkait kepentingan negaranya dengan Malaysia. Di sisi lain, skenario ini tidak terjadi di Malaysia. Jarang sekali orang Malaysia menunjukkan sikap agresifnya ketika menghadapi masalah yang melibatkan Malaysia. Apakah sikap ini karena kurangnya pengetahuan dan pemahaman mereka tentang hubungan kedua negara?.

Pertanyaannya mengapa masyarakat Indonesia begitu sensitif terhadap Malaysia dibandingkan dengan negara tetangga lainnya?. Menurut Shariva, dalam hal ini peran media massa khususnya di Indonesia dipandang sangat signifikan. Penyebaran informasi khususnya di kalangan surat kabar swasta di Indonesia mengenai isu-isu terkini tentang Malaysia sangat bebas. Mereka menerbitkan banyak berita hangat yang bertujuan untuk meningkatkan penjualan surat kabar mereka. Penyebaran berita yang tidak diseleksi oleh pihak berwenang telah memberikan stigma negatif terhadap pandangan masyarakat mereka tentang Malaysia. ${ }^{8}$

Tidak dapat dinafikan bahwa hubungan Indonesia dan Malaysia merupakan hubungan yang istimewa namun dalam waktu yang bersamaan hubungan tersebut tetap terekspos terhadap berbagai persoalan sebagaimana dijelaskan oleh A Effendy Choirie, "keduanya adalah negeri serantau, tetangga terdekat, tetapi sering diliputi kesalahpahaman". 9

Dari sisi lain, masalah hubungan Malaysia-Indonesia juga muncul karena sikap Indonesia yang dipengaruhi oleh rasa kebanggaan (sense of entitlement) yang tinggi. Menurut Ruhanas Harun, berdasarkan sikap tersebut mereka ingin negara-negara serantau mengakui kedudukan mereka. Mantan Menteri Luar Negeri RI, Ali Alatas pernah menyatakan bahwa "Malaysians are arrogant, Indonesians are jealous" saat

${ }^{8}$ Shariva Alaidrus, "Menteri Malaysia Beri Penghargaan Kepada Wartawan Senior" dalam http://www.antaranews.com/berita/611434/menteri-malaysia-beri-peng hargaan-kepada-wartawan-senior diakses 23 Oktober 2017.

${ }^{9} \mathrm{~A}$ Effendy Choirie, "Membangun Saling Pengertian Antara Indonesia dan Malaysia" dalam https://www.nu.or.id/post/read/17989/membangun-saling-pengertian-antara-indonesia-dan-malaysia diakses 23 Oktober 2017. 
memberikan pandangan tentang hubungan bilateral kedua negara. ${ }^{10}$ Faktor ini juga dipandang sebagai unsur yang mempengaruhi sikap dan penerimaan masyarakat Indonesia ketika dihadapkan pada isu-isu yang berkaitan dengan Malaysia. Sebagai perbandingan, sikap mereka tidak begitu agresif jika menghadapi situasi serupa dengan negara tetangga lainnya.

Seorang pakar akademik Universiti Malaya, Dr. Amri Marzali berpandangan bahwa semangat serumpun yang semakin terkikis di kalangan rakyat Indonesia berpeluang berkontribusi atas kekecewaan dan tuduhan sikap 'arogan' saudara serumpun di Malaysia. Menurut Amri, orang Melayu di Indonesia melihat orang Melayu di Malaysia jauh lebih maju dalam berbagai bidang, terutama pembangunan dan kemajuan ekonomi negara. Lebih lanjut Amri mengatakan bahwa tidak dapat dipungkiri ada sedikit kecemburuan masyarakat Indonesia terhadap keberhasilan Malaysia, terutama pada masa pemerintahan mantan Perdana Menteri Tun Dr. Mahathir Mohamad dan pada tingkat tertentu mempengaruhi hubungan masyarakat antara kedua negara. ${ }^{11}$ Sementara itu, pakar politik luar negeri Indonesia, Zainuddin Djafar di dalam satu diskusi di Indonesia yang mengulas tentang tindakan Malaysia atas Ambalat menyatakan bahwa nilai sentimen dalam sejarah hubungan kedua negara bukan lagi isu yang signifikan, "Mereka tidak lagi merisaukan masa lalu. Kejayaan Indonesia sudah dianggap selesai di mata mereka dan tidak ada lagi istilah tentang abang adik, saudara tua". 12

Isu terbaru adalah pengibaran bendera Indonesia secara terbalik pada acara SEA Games Kuala Lumpur 2017. Kesalahan ini memicu reaksi di kalangan masyarakat Indonesia. Reaksi awal di antaranya disampaikan oleh Wakil Komisi 1 Dewan Perwakilan Rakyat Republik Indonesia (DPR RI), Meutya Hafid yang menyatakan,

${ }^{10}$ Ruhanas Harun, "Kerjasama dan konflik dalam hubungan Malaysia-Indonesia" dalam Ruhanas Harun (Ed.), Malaysia's Foreign Relations: Issues and Challenges (Kuala Lumpur: University of Malaya Press, 2006).

${ }^{11}$ Mingguan Malaysia, 16 Januari 2011.

${ }^{12}$ Kompas.com, "Malaysia Takut Dengan Indonesia" dalam http:// nasional.kompas.com/read/2010 /08 /30/19132967/Malaysia.Takut.dengan.Indonesia diakses 23 Oktober 2017. 
"terbaliknya bendera Indonesia dalam materi pertandingan persahabatan SEA Games adalah kecerobohan yang melukai rasa persahabatan kedua negara". ${ }^{13}$

Sebagaimana yang dinyatakan sebelumnya, konflik dan kerjasama sering muncul secara berselang seling dalam hubungan Malaysia-Indonesia. Dalam tempo lebih dari enam dekade hubungan Malaysia-Indonesia, tidak dapat dinafikan bahwa kepentingan hubungan kedua negara kini lebih bersandarkan pada kepentingan ekonomi. Malaysia Global Chambers of Commerce (MGCC) pernah mengemukakan kepentingan hubungan ini dalam pernyataannya bahwa "Malaysia merupakan mitra dagang terbesar Indonesia dengan nilai sekitar 24 miliar dolar AS, selain merupakan negara investor terbesar di republik terkait". Lebih jauh dikatakan bahwa investor Malaysia banyak berinvestasi dalam sektor kelapa sawit, perbankan, telekomunikasi dan kesehatan di Indonesia. ${ }^{14}$ Persoalan ini diakui sendiri oleh Perdana Menteri Malaysia, Datuk Seri Najib Tun Razak bahwa Malaysia senantiasa menganggap hubungan bilateral dengan Indonesia sebagai hubungan dalam sebuah keluarga yang diumpamakan dengan "air yang dicincang tak akan putus". 15

\section{Metode Penelitian}

Penelitian ini menggunakan mixed method yaitu kuantitatif dan kualitatif. Metode penelitian perintis diaplikasikan dengan menggunakan daftar pertanyaan kuesioner untuk memperoleh data. Metode kuantitatif dan kualitatif ini digunakan karena metode ini sering diterapkan dalam berbagai penelitian baik di dalam maupun di luar negeri. Melalui desain penelitian ini, data tidak hanya diperoleh dan disajikan secara empiris tetapi juga dapat mendukung generalisasi temuan penelitian.

Data diperoleh melalui penyebaran kuesioner kepada responden. Responden terdiri dari staf administrasi dan staf akademik serta mahasiswa UUM yang mewakili dua Gen yaitu X dan Y. Kuesioner dilakukan untuk memperoleh informasi tentang

\footnotetext{
${ }^{13}$ Gibran Maulana Ibrahim, "Bendera Indonesia Terbalik di SEA Games 2017 Lukai Rasa Persahabatan” dalam https://news.detik.com/berita/d-3606334/bendera-indonesia-terbalik-di-sea-games2017-lukai-rasa-persahabatan diakses 20 Oktober 2017.

${ }^{14 N i d i a}$ Zuraya, "Investor: Hubungan Ekonomi Malaysia-Ri Semakin Baik" dalam https://www.republika.co.id/berita/ekonomi/bisnis-global/17/05/15/opzi9c383-investor-hubunganekonomi-malaysiari-makin-baik diakses 12 Maret 2020.

${ }^{15}$ Bernama, "Hubungan Malaysia-Indonesia Ibarat Sebuah Keluarga - PM Najib” dalam http:/ /www.astroawani.com/berita-malaysia/hubungan-malaysia-indonesia-ibarat-sebuah-keluarga-pm-najib155820 diakses 19 Juni 2020.
} 
faktor dan persepsi yang mempengaruhi responden tentang hubungan MalaysiaIndonesia. Kuesioner dibagikan kepada responden yang dipilih secara asesmen/expert sampling (purposive sampling). Responden Gen $\mathrm{Y}$ adalah mahasiswa terpilih yang sedang mengikuti program sarjana (S1) dari berbagai program. Sedangkan Gen X adalah responden berusia 40 tahun ke atas yang merupakan staf, akademisi, dan mahasiswa di luar UUM. Pemilihan sampel dan lokasi penelitian yang ditentukan di UUM didasarkan pada kriteria objektif sampling. Tabel 1 menampilkan karakteristik demografi responden berdasarkan kriteria jenis kelamin, usia dan ras.

Kuisioner disusun berdasarkan tinjauan pustaka tentang isu-isu yang sering disiarkan dalam surat kabar, media sosial dan penelitian-penelitian sebelumnya. Selain itu, data-data penelitian juga diperoleh melalui wawancara dengan pakar-pakar yang mempunyai otoritas dalam membahas tentang keterlibatan masyarakat dalam hubungan antara kedua negara. Mereka yang diwawancarai merupakan mantan Atase Pendidikan Malaysia di Jakarta, pakar akademik lokal yang pernah mengabdi di universitas di Indonesia dan ahli-ahli akademik Indonesia yang pernah bertugas Malaysia. Data-data penelitian juga diperoleh melalui penelitian kepustakaan secara analisis isi dari bukubuku, artikel jurnal, laporan-laporan surat kabar.

Tabel 1.

Demografi Responden

Karakteristik Demografi Responden

\begin{tabular}{lccclc}
\hline $\begin{array}{c}\text { Jenis } \\
\text { Kelamin }\end{array}$ & Persen(\%) & Umur & Persen(\%) & Bangsa & Persen(\%) \\
\hline Laki-laki & 22.3 & $20-25$ & 94.8 & Melayu & 70.8 \\
\hline Perempuan & 77.7 & $26-30$ & 1.9 & Cina & 23.2 \\
\hline & & $31-35$ & 3.3 & India & 3.4 \\
\hline Jumlah & 100.0 & & & Lain-Lain & 2.6 \\
\hline
\end{tabular}

Dalam upaya memahami status hubungan Malaysia-Indonesia kontemporer, studi ini melihat realisasi indikator sifat dan karakter hubungan bilateral berdasarkan reaksi publik di kedua negara terhadap isu-isu terkini. Selain aktor dan faktor geopolitik, tampilan sikap dan reaksi masyarakat awam tentang apa yang diketahui dan 
dipahami juga mempengaruhi iklim hubungan kedua negara. Dengan demikian, penelitian ini mengkaji tingkat pengetahuan dan pemahaman Gen X dan Y di UUM tentang hubungan bilateral Malaysia-Indonesia berdasarkan isu dan sumber pengetahuan yang dibentuk menjadi instrumen memperoleh data yang berisi kategori sebagai berikut:

1). Pembacaan surat kabar lokal.

2). Menjelajahi media sosial.

3). Sumber informasi dari universitas.

4). Berdiskusi dengan rekan-rekan dari Indonesia melalui tatap muka.

5). Berdiskusi dengan rekan-rekan dari Indonesia secara on-line.

6). Menonton film atau sinetron Indonesia.

Data yang diperoleh melalui instrumen ini dianalisis dengan menggunakan Statistical Packages for Social Sciences versi 16.0 (SPSS 16.0). Pembahasan selanjutnya merangkum hasil penelitian yang diolah dengan menggunakan metode analisis deskriptif.

\section{Pembacaan Surat Kabar Lokal}

Surat kabar merupakan media penyebaran informasi yang memiliki pengaruh yang luas. Kekuatan surat kabar dalam mempengaruhi persepsi publik telah terbukti sejak dahulu kala karena merupakan saluran informasi utama bagi kebanyakan orang. Dengan demikian, penelitian ini menyoroti peran surat kabar dalam membentuk pengetahuan dan persepsi kedua gen tersebut tentang negara Indonesia. Responden diminta untuk menyatakan persetujuannya atas fakta bahwa mereka sering membaca tentang Indonesia di surat kabar lokal. Hasil survei sebagaimana tercantum pada Tabel 2 menunjukkan bahwa di antara Gen Y sebanyak 65 responden atau 17,7\% sangat tidak setuju, sedangkan 105 responden atau 28,5\% tidak setuju. Sedangkan sebanyak 112 responden atau 30,5\% dan 4 responden atau 1,1\% masing-masing setuju dan sangat setuju dengan pernyataan tersebut. Selain itu, 86 responden atau 23,4\% menyatakan ketidakpastian. Setelah dibandingkan dengan Gen X, survei menemukan hanya satu responden atau 2,0\% yang menyatakan sangat tidak setuju dan mayoritas responden yaitu 20 orang atau 40,8\% setuju untuk sering membaca berita melalui surat kabar tentang Indonesia. 
Tabel 2.

Distribusi jawaban untuk item

"Saya sering membaca berita tentang Indonesia melalui surat kabar lokal"

\begin{tabular}{lcccc} 
Saya sering membaca berita tentang & \multicolumn{2}{c}{ Gen $\boldsymbol{c}$} & \multicolumn{2}{c}{ Gen X } \\
\cline { 2 - 5 } Indonesia melalui surat kabar lokal & Frekuensi & Persen(\%) & Frekuensi & Persen(\%) \\
\hline Sangat tidak setuju & 65 & 17.7 & 1 & 2.0 \\
\hline Tidak setuju & 105 & 28.5 & 15 & 30.6 \\
\hline Tidak Pasti & 86 & 23.4 & 12 & 24.5 \\
\hline Setuju & 107 & 29.1 & 20 & 40.8 \\
\hline Sangat Setuju & 5 & 1.4 & 1 & 2.0 \\
\hline Jumlah & 368 & 100.0 & 49 & 100.0
\end{tabular}

\section{Menjelajahi Media Sosial}

Penggunaan media sosial begitu popular di kalangan Gen Y. Penyebaran informasi melalui media sosial tersebut mempunyai pengaruh yang cukup luas. Pada umumnya mereka pengakses platform-platform utama seperti Facebook, Instagram dan Twitter. Penelitian ini menyoroti peranan media sosial dalam membentuk pengetahuan kedua Gen tentang eksistensi negara tetangga Indonesia. Responden diminta menyatakan persetujuan mereka terhadap kenyataan apakah mereka sering membaca tentang negara Indonesia dalam media sosial. Hasil penelitian seperti terlihat pada Tabel 3 menunjukkan bahwa di kalangan Gen Y sebanyak 64 responden atau 17,4\% menyatakan sangat tidak setuju sedangkan 115 responden atau 31,3\% tidak setuju. Sedangkan sebanyak 95 responden atau 26,0\% dan 4 responden atau 1,1\% masingmasing setuju dan sangat setuju dengan pernyataan tersebut. Selain itu, sebanyak 93 responden atau 25,3\% menyatakan ketidakpastian. Sebaliknya, kelompok Gen X umumnya tidak setuju, yaitu 16 responden atau 32,7\%, sedangkan 14 responden atau $28,6 \%$ setuju. Hanya 2 responden sangat setuju dan 8 responden atau 16,3\% menjawab ragu-ragu. 
Tabel 3.

Distribusi jawaban untuk item "Menjelajahi Media Sosial"

\begin{tabular}{lccccc}
\multirow{2}{*}{ Menjelajahi Media Sosial } & \multicolumn{2}{c}{ Gen } & \multicolumn{2}{c}{ Gen $\boldsymbol{~}$} \\
\cline { 2 - 5 } & Frekuensi & Persen(\%) & Frekuensi & Persen(\%) \\
\hline Sangat tidak setuju & 64 & 17.4 & 8 & 16.3 \\
\hline Tidak setuju & 115 & 31.3 & 16 & 32.7 \\
\hline Tidak Pasti & 93 & 25.3 & 8 & 16.3 \\
\hline Setuju & 90 & 24.5 & 14 & 28.6 \\
\hline Sangat Setuju & 5 & 1.4 & 2 & 4.1 \\
\hline Jumlah & 367 & 99.7 & 48 & 98.0
\end{tabular}

\section{Sumber Informasi dari Universitas}

Selain dari Thailand, Indonesia merupakan negara yang agak dekat dengan UUM dibandingkan dengan negara tetangga yang lain. Beberapa universitas di Indonesia telah menjalin hubungan dengan UUM melalui MoU dan pertukaran mahasiswa. Berita-berita mengenai Indonesia sering diumumkan melalui media elektronik UUM dan juga surat kabar universitas. Tabel 4 di bawah ini menunjukkan temuan responden yang menerima informasi dari perguruan tinggi tentang situasi di Indonesia. Sebanyak 38 responden atau 10,3\% untuk Gen Y tidak setuju sedangkan 63 responden atau 17,1\% setuju. Mayoritas responden tidak yakin yaitu 173 atau 47,0\%. Sedangkan Gen X umumnya menjawab tidak pasti yaitu 22 responden atau 44,9\% dan diikuti setuju yaitu 11 responden atau 22,4\%. Hanya 13 responden yang menjawab sangat tidak setuju dan tidak setuju yang juga sebesar $26,5 \%$. Hanya satu responden atau 2,0\% yang menjawab sangat setuju.

Tabel 4.

Distribusi jawaban untuk item "Sumber Informasi Dari Universiti"

\begin{tabular}{lcccc}
\multirow{2}{*}{ Sumber Informasi daripada Universiti } & \multicolumn{2}{c}{ Gen $\boldsymbol{c}$} & \multicolumn{2}{c}{ Gen $\boldsymbol{X}$} \\
\cline { 2 - 5 } & Kekerapan & Persen(\%) & Kekerapan & Persen(\%) \\
\hline Sangat tidak setuju & 38 & 10.3 & 5 & 10.2 \\
\hline Tidak setuju & 85 & 23.1 & 8 & 16.3 \\
\hline Tidak Pasti & 173 & 47.0 & 22 & 44.9 \\
\hline Setuju & 63 & 17.1 & 11 & 22.4
\end{tabular}




\begin{tabular}{lccccc}
\multirow{2}{*}{ Sumber Informasi daripada Universiti } & \multicolumn{2}{c}{ Gen $Y$} & \multicolumn{2}{c}{ Gen $\boldsymbol{X}$} \\
\cline { 2 - 5 } & Kekerapan & Persen(\%) & Kekerapan & Persen(\%) \\
\hline Sangat Setuju & 8 & 2.1 & 1 & 2.0 \\
\hline Jumlah & 368 & 100.00 & 47 & 95.9
\end{tabular}

\section{Berdiskusi Dengan Rekan-Rekan Dari Indonesia Secara Tatap Muka}

UUM memiliki 20\% mahasiswa internasional. Beberapa di antaranya berasal dari benua Afrika, Asia Barat, Asia Kecil dan negara-negara ASEAN. Mahasiswa Indonesia merupakan mayoritas mahasiswa internasional di UUM. Berdasarkan kesamaan budaya, agama dan bahasa, siswa Indonesia lebih mudah berinteraksi dengan siswa lokal dibandingkan dengan siswa dari negara lain. Tabel 5 menunjukkan temuan responden yang berdiskusi dengan rekan dari Indonesia secara tatap muka. Sebanyak 142 atau 38,6\% menyatakan sangat tidak setuju, sedangkan 94 responden atau 25,5\% tidak setuju. Diikuti oleh total 69 atau 18,8\% responden yang menyatakan ketidakpastian. Sebanyak 52 atau $14,1 \%$ responden menyatakan setuju pernah berdiskusi tatap muka dengan mahasiswa asal Indonesia. Sedangkan sebanyak 10 responden Gen Y menyatakan sangat setuju atau sebanyak 2,7\%. Sementara itu, Gen X tidak setuju dengan 17 orang atau 34,7\% sedangkan 12 orang atau 24,5\% sangat tidak setuju. Selain itu, responden yang menjawab ragu-ragu sebanyak 11 orang atau $22,4 \%$. Untuk jawaban setuju dan tidak setuju sebanyak 7 orang atau 14,2\%.

Tabel 5.

Distribusi jawaban untuk item

"Berdiskusi Dengan Rekan-Rekan Dari Indonesia Secara Face to Face”

\begin{tabular}{lccccc}
\multirow{2}{*}{$\begin{array}{c}\text { Berdiskusi Dengan Rekan-Rekan Dari } \\
\text { Indonesia Secara Face to Face }\end{array}$} & \multicolumn{2}{c}{ Gen Y } & \multicolumn{2}{c}{ Gen X } \\
\cline { 2 - 5 } & Kekerapan & Persen(\%) & Kekerapan & Persen(\%) \\
\hline Sangat tidak setuju & 142 & 38.6 & 12 & 24.5 \\
\hline Tidak setuju & 94 & 25.5 & 17 & 34.7 \\
\hline Tidak Pasti & 69 & 18.8 & 11 & 22.4 \\
\hline Setuju & 52 & 14.1 & 6 & 12.2 \\
\hline Sangat Setuju & 10 & 2.7 & 1 & 2.0 \\
\hline Jumlah & 367 & 99.7 & 47 & 95.9
\end{tabular}




\section{Berdiskusi Dengan Rekan-Rekan Dari Indonesia Secara Virtual}

Media sosial mendekatkan jarak komunikasi antar negara. Tabel 6 menunjukkan temuan responden yang berdiskusi dengan rekan dari Indonesia hampir sama melalui Facebook, Twitter, Instagram, Snapchat dan lain-lain. Sebanyak 171 responden atau 46,5\% menjawab sangat tidak setuju diikuti oleh 94 responden atau 25,5\% tidak setuju. Hanya 38 responden yang memilih jawaban setuju dan sangat setuju yaitu 10,3\% saja. Sedangkan 64 responden atau 17,4\% menyatakan ketidakpastian. Sedangkan untuk Gen $\mathrm{X}$ juga menjawab sangat tidak setuju yaitu 20 orang atau $40,8 \%$ diikuti yang menjawab ragu-ragu sebanyak 12 orang atau 24,5\%. Hanya 6 responden yang setuju atau 12,2\%. Sedangkan 11 responden yang menjawab tidak setuju atau 11,4\%.

Tabel 6.

Distribusi jawaban terhadap item

"Berdiskusi Dengan Rekan-Rekan Dari Indonesia Secara Virtual”

\begin{tabular}{lcccc}
\multirow{2}{*}{\begin{tabular}{c} 
Berdiskusi Dengan Rekan-Rekan Dari $\begin{array}{c}c \\
\text { Indonesia Secara Virtual }\end{array}$ \\
\cline { 2 - 5 }
\end{tabular}} & Kekerapan & Persen(\%) & Kekerapan & Persen(\%) \\
\hline Sangat tidak setuju & 171 & 46.5 & 20 & 40.8 \\
\hline Tidak setuju & 94 & 25.5 & 11 & 22.4 \\
\hline Tidak Pasti & 64 & 17.4 & 12 & 24.5 \\
\hline Setuju & 32 & 8.7 & 6 & 12.2 \\
\hline Sangat Setuju & 6 & 1.6 & 0 & 0.0 \\
\hline Jumlah & 368 & 100.00 & 49 & 100.0
\end{tabular}

\section{Menonton Film atau Sinetron Indonesia}

Film pendek dan sinetron Indonesia menjadi pilihan masyarakat Malaysia. Tabel 7 menunjukkan temuan Gen Y dalam menonton film dan sinetron Indonesia. Dibandingkan temuan lainnya, mayoritas responden setuju yaitu 151 atau 40,4 diikuti 48 responden sangat setuju atau $12,8 \%$. Sedangkan yang lainnya menjawab tidak pasti yaitu 90 atau $24,1 \%$ dan 34 responden sangat tidak setuju diikuti 51 responden tidak setuju atau $13,6 \%$. 
Tabel 7.

Distribusi respon untuk item "Menonton Filem atau Sinetron Indonesia"

\begin{tabular}{lcccc}
\multirow{2}{*}{$\begin{array}{c}\text { Menonton Filem atau Sinetron } \\
\text { Indonesia }\end{array}$} & \multicolumn{2}{c}{ Gen $\boldsymbol{c}$} & \multicolumn{2}{c}{ Gen $\boldsymbol{~}$} \\
\cline { 2 - 5 } & Kekerapan & Persen(\%) & Kekerapan & Persen(\%) \\
\hline Sangat tidak setuju & 34 & 9.2 & 5 & 10.2 \\
\hline Tidak setuju & 49 & 13.3 & 12 & 24.5 \\
\hline Tidak Pasti & 87 & 23.6 & 16 & 32.7 \\
\hline Setuju & 149 & 40.5 & 11 & 22.4 \\
\hline Sangat Setuju & 49 & 13.3 & 5 & 10.2 \\
\hline Jumlah & 368 & 100.0 & 49 & 100.0
\end{tabular}

\section{Diskusi Hasil Penelitian}

Hasil penelitian menunjukkan bahwa membaca merupakan faktor penting dalam mempengaruhi tingkat pengetahuan dan pemahaman Gen Y di Malaysia tentang Indonesia. Dengan membaca koran lokal, mereka mendapatkan informasi dengan mudah tentang isu-isu yang berlaku di negara tetangga. Hampir $70 \%$ Gen Y memiliki informasi tentang Indonesia. Peran penting media massa diakui oleh J. Junaidi yang menyatakan bahwa surat kabar di Indonesia dan di Malaysia menganggap hubungan Malaysia dan Indonesia penting untuk disiarkan dan memiliki pengaruh yang besar di antara masyarakat kedua negara. ${ }^{16}$ Hal ini menyebabkan Gen Y memiliki pemahaman yang baik tentang hubungan Malaysia dan Indonesia. Media sosial berperan penting dalam menyebabkan dua generasi ini memiliki informasi tentang Indonesia. Gen Y menggunakan Facebook, Twitter, media sosial untuk mendapatkan informasi berita dan perkembangan terkini di Indonesia tentang politik, pendidikan, ekonomi dan hiburan di negara tersebut. Pentingnya peran media sosial dalam hubungan Malaysia-Indonesia diakui oleh Siti Ezaleila Mustafa, yang menyatakan bahwa jumlah netizen adalah 17 juta di Malaysia dan 40 juta di Indonesia, sehingga tidak dapat disangkal bahwa informasi yang terkandung di media sosial sangat berpengaruh. ${ }^{17}$

Bagi Gen Y di UUM, rekan-rekan juga menjadi sumber untuk mengetahui mengenai situasi terkini dan sejarah Indonesia. Sedangkan bagi mahasiswa Indonesia

${ }^{16} \mathrm{~J}$. Junaidi, "Pandangan Editor Surat Kabar Terhadap Jurnalisme Multikultural" dalam Jurnal Ilmu Komunikasi (JIK), Vol. 8, No. 2 (2014), h. 105-116.

${ }^{17}$ Siti Ezaleila Mustafa, "Media sosial di Malaysia dan Indonesia: Penggunaannya Sebagai Alat Komunikasi, Kolaborasi dan Jaringan Digital” dalam Jurnal Pengajian Media, Vol. 15. No. 2 (2013), h. 71-85. 
yang belajar di UUM, mereka merasakan Malaysia seperti rumah mereka sendiri karena persamaan bangsa, agama dan budaya. ${ }^{18}$ Ada juga mahasiswa UUM mempunyai rekan dari Indonesia dan mereka berkongsi pandangan melalui hubungan virtual media sosial seperti Facebook dan Twitter.

Nilai tambah pengetahuan dan pemahaman Gen Y juga disumbangkan oleh Gen Y yang sangat tertarik mendengarkan lagu dan sinetron dari Indonesia. Selain lagu pop, ritme dangdut juga menjadi pilihan Gen Y. Bahkan ada juga Gen Y yang tertarik dengan artis Indonesia karena cantik dan berbakat. Alur cerita yang melankolis tidak hanya menceritakan kisah cinta yang klise tetapi juga memiliki unsur kemanusiaan yang menggetarkan jiwa yang berhasil meningkatkan rating penonton, khususnya Gen Y. Hiburan antara kedua negara tidak terbatas pada mahasiswa UUM saja. Mahasiswa Indonesia yang kuliah di UUM juga tertarik dengan seniman Malaysia. Lagu-lagu sentimental dan modern sangat digemari oleh pelajar Indonesia.

Tingginya pemahaman responden tentang hubungan baik Malaysia-Indonesia juga mempengaruhi pemilihan produk Indonesia. Produk kesehatan dan kecantikan memberikan kepercayaan kepada Gen Y untuk digunakan dalam kehidupan sehari-hari. Berdasarkan penelitian Levi Mayang Pramudita dan Samsudin A. Rahim, produk Indonesia sangat disukai oleh Gen Y, terutama pembelian melalui internet. Gen Y lebih suka membeli produk Indonesia seperti produk kecantikan dan produk pelangsing tubuh. ${ }^{19}$ Pemilihan kosmetik dan obat kesehatan merupakan produk yang banyak dibeli dari Indonesia. Hal ini jelas menunjukkan hubungan Indonesia dan Malaysia yang erat dengan pembelian barang lintas batas.

Secara umum, pengetahuan yang tinggi dan pemahaman positif di kalangan mahasiswa sangat penting dalam membentuk arah hubungan Malaysia-Indonesia di masa depan. Hal ini karena mereka adalah kelompok pendukung yang akan menjadi pemimpin politik, pemimpin dalam organisasi dan mereka yang akan menjadi juru

${ }^{18}$ Muhammad Saleh Tajuddin, Guru Besar UIN Alauddin Makassar-Universiti Utara Malaysia, wawancara, 2017.

${ }^{19}$ Levi Mayang Pramudita \& Samsudin A. Rahim, "Periklanan Internet: Faktor Pendorong yang Merangsang Pembelian Produk Kecantikan" dalam Malaysian Journal of Communication, Vol. 27, No. 1 (2011), h. 1-17. 
bicara masyarakat. Kelompok ini mungkin suatu saat memiliki kepentingan dalam hubungan dengan Indonesia. ${ }^{20}$

\section{Kesimpulan}

Baik di Malaysia maupun di Indonesia, Gen Y adalah kelompok terpenting dalam masyarakat. Mereka adalah generasi pemimpin dan mampu membentuk masa depan bangsa. Dalam konteks hubungan bilateral, tingkat pemahaman dan persepsi positif yang tinggi dapat menjadi nilai tambah dalam hubungan Malaysia-Indonesia. Oleh karena itu, upaya peningkatan pemahaman dan persepsi positif kedua negara perlu diintensifkan demi kepentingan bersama. Tidak dapat disangkal bahwa hubungan Malaysia-Indonesia seringkali dibayangi oleh kepentingan nasional. Pertanyaan ini juga menjadi duri dalam daging dalam hubungan. Namun, kepentingan nasional juga dapat dijadikan dasar kerjasama Malaysia-Indonesia. Oleh karena itu, institusi yang dekat dengan Gen Y seperti universitas dan perguruan tinggi, perusahaan surat kabar dan penerbitan, lembaga hiburan serta Lembaga Swadaya Masyarakat (LSM) perlu ditingkatkan perannya dalam memberikan pengetahuan dan pemahaman yang baik di kalangan Gen muda tentang negara Indonesia. Meningkatkan persepsi yang lebih positif tentang kedua negara di antara Gen muda berintegritas dapat memperkuat kerja sama Indonesia-Malaysia dalam menciptakan lingkungan yang saling menguntungkan antara kedua negara.

\section{DAFTAR PUSTAKA}

Ghani, Rohani Hj. Ab. "Dinamika Hubungan Malaysia-Indonesia: Satu RetroPerspektif" dalam Seminar Internasional Malaysia-Indonesia, Fakultas Usuluddin dan Falsafat UIN Alauddin Makassar, 16-17 Oktober 2016.

Hamzah, Intan Suria \& Sity Daud. "Implikasi Kemasukan Pekerja Asing di Malaysia: Satu Tinjauan Awal” dalam Jurnal Sains Insani, Vol. 1, No. 1 (2016), h. 69-77.

Harun, Ruhanas. "Kerjasama dan konflik dalam hubungan Malaysia-Indonesia" dalam Ruhanas Harun (Ed.). Malaysia's Foreign Relations: Issues and Challenges. Kuala Lumpur: University of Malaya Press, 2006.

${ }^{20}$ Junaidi Abu Bakar, Universiti Utara Malaysia, wawancara, 2017. 
Junaidi, J. "Pandangan Editor Surat Kabar Terhadap Jurnalisme Multikultural" dalam Jurnal Ilmu Komunikasi (JIK), Vol. 8, No. 2 (2014), h. 105-116.

Kassim, Azizah. "International Migration and its Impact on Malaysia" dalam Mohamed Jawhar Hassan (ed.). A Pacific Peace: Issues \& Responses. Kuala Lumpur: Institute Strategic and International Security, 1998.

Mak, Joon Num. Domestic Politics and Conflict-Resolution in the South China Sea: China and the Spratly Disputes. Tidak Diterbitkan, 2000.

Mustafa, Siti Ezaleila. "Media sosial di Malaysia dan Indonesia: Penggunaannya Sebagai Alat Komunikasi, Kolaborasi dan Jaringan Digital" dalam Jurnal Pengajian Media, Vol. 15. No. 2 (2013), h. 71-85.

Pramudita, Levi Mayang \& Samsudin A. Rahim. "Periklanan Internet: Faktor Pendorong yang Merangsang Pembelian Produk Kecantikan” dakam Malaysian Journal of Communication, Vol. 27, No. 1 (2011)., 1-17.

Ruzui, Septy. A Survey of Relations Between Indonesian, Malay and Some Philippine Languages. Kuala Lumpur: Dewan Bahasa dan Pustaka, 1986.

Yakub, Ahmad Nizar. Dances with Garuda: Malaysia-Indonesia Bilateral Relations. Samarahan: Universiti Malaysia Sarawak, 2013.

\section{Internet}

Alaidrus, Shariva. "Menteri Malaysia Beri Penghargaan Kepada Wartawan Senior" dalamhttp://www.antaranews.com/berita/611434/menteri-malaysia-beri-penghar gaan-kepada-wartawan-senior diakses 23 Oktober 2017.

Bernama. "Hubungan Malaysia-Indonesia Ibarat Sebuah Keluarga - PM Najib" dalam http://www.astroawani.com/berita-malaysia/hubungan-malaysia-indonesiaibarat-sebuah-keluarga-pm-najib-155820 diakses 19 Juni 2020.

Bernama. "Lebih 1.7 Juta Pekerja Asing Pemegang Pas Lawatan Kerja Sementara" dalam http://www.astroawani.com/berita-malaysia/lebih-1-7-juta-pekerja-asingpemegang-pas-lawatan-kerja-sementara-150996 diakses 23 Oktober 2017.

Choirie, A Effendy. "Membangun Saling Pengertian Antara Indonesia dan Malaysia" dalam https://www.nu.or.id/post/read/17989/membangun-saling-pengertianantara-indonesia-dan-malaysia diakses 23 Oktober 2017.

Ibrahim, Gibran Maulana. "Bendera Indonesia Terbalik di SEA Games 2017 Lukai Rasa Persahabatan" dalam https://news.detik.com/berita/d-3606334/benderaindonesia-terbalik-di-sea-games-2017-lukai-rasa-persahabatan diakses 20 Oktober 2017. 
Kompas.com. "Malaysia Takut Dengan Indonesia" dalam http://nasional.kompas.com /read/2010 /08 /30/19132967/Malaysia.Takut.dengan .Indonesia diakses 23 Oktober 2017.

Zuraya, Nidia. "Investor: Hubungan Ekonomi Malaysia-Ri Semakin Baik" dalam https://www.republika.co.id/berita/ekonomi/bisnis-global/17/05/15/opzi9c383investor-hubungan-ekonomi-malaysiari-makin-baik diakses 12 Maret 2020.

\section{Wawancara}

Junaidi Abu Bakar, Universiti Utara Malaysia, wawancara, 2017.

Muhammad Saleh Tajuddin, UIN Alauddin Makassar-Universiti Utara Malaysia, wawancara, 2017. 